REBECCA ELISE EATON

\title{
THE LEGITIMACY OF SPECTRAL EVIDENCE DURING THE SALEM WITCHCRAFT TRIALS
}

Submitted for the LLB (Honours) Degree

Faculty of Law

Victoria University of Wellington

2013 
Abstract

This paper looks at the use of spectral evidence during the Salem witch trials and examines whether its use was legitimate and in accordance with the evidential standards of the time (1692). Ultimately this paper finds that the use of spectral evidence was legitimate as it followed the slim guidelines available at the time. The court followed a strong precedent and the limited statutory guidance and instructions that were available. However there was acknowledgement at the time that spectral evidence was limiting the rights of those accused and was leading to unjust convictions. As such these trials invoked an acknowledgement of more modern standards of evidence. Therefore spectral evidence was legitimately used given the guidelines of the time despite the unjust effect that it had.

Key words: Salem, witchcraft trials, spectral evidence 


\section{Contents}

I. Introduction........................................... 4

II. Background to the trials.................................4

III. Legal Procedure........................................ 7

a. Establishment of court, juries and judges.................7

b. Evidence used.......................................... 7

IV. Spectral Evidence.......................................9

a. Background...........................................

b. How Spectral Evidence was used in the trials..............10

c. How heavily was Spectral Evidence relied upon?................12

d. Use of evidence was informed by popular beliefs...........13

V. Spectral Evidence and evidential standards of the time..........14

a. Guidance given on the use of Spectral Evidence............14

i. Case law........................................14

ii. Statute......................................... 15

iii. Legal texts...................................15

b. General evidential standards of the time....................17

c. Did the court follow these guidelines?..................................17

d. Juries.................................................18

e. Judges and Ministers..................................20

f. Critics of Spectral Evidence at the time....................22

g. Rationale for allowing Spectral Evidence.................25

h. The eventual discrediting of Spectral Evidence and the end

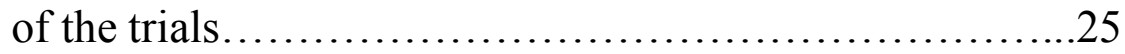

VI. Fallout from the trials ...................................28

VII. Conclusion..............................................29 


\section{Introduction}

The Salem witchcraft trials of 1692 are well known throughout the world and have been immortalised in literature and film, such as Arthur Miller's The Crucible. Whilst known by many within popular culture as an example of witchcraft persecution, the trials also offer an insight into the legal procedures and standards of colonial America in the $17^{\text {th }}$ Century. These trials are perhaps best known by many legal historians for the seemingly unprecedented use of spectral evidence, which played a role in the conviction of 19 individuals for witchcraft. Spectral evidence involved the accounts of the accusers that the 'spectre' of the accused had harmed them on the instructions of the Devil. It is this particular form of evidence which will be examined in this paper. In particular, this paper will look at whether the use of this evidence was legitimate given the legal standards of the time. The thesis of this paper is that spectral evidence was used within the slim evidential standards available in 1692, however there was also an acknowledgement at the time that the effect of using this evidence resulted in unjust convictions. As such, the legal fraternity at Salem in 1692 was on the precipice of acknowledging more modern procedural and evidential standards by which the use of spectral evidence would have been disallowed.

This argument will be proven by looking at the legal procedure established for the trials, how spectral evidence was used during this episode and how heavily it was relied upon. The precedents and legal rules in existence at the time are examined as well as the role played by the judges, juries and opponents of spectral evidence. Finally the discrediting of spectral evidence and the fallout from the trials will be examined.

\section{Background to the Trials}

The Salem trials resulted from the mysterious affliction of various young girls in Salem Village, Massachusetts. The original afflicted girls were Betty Parris and her cousin Abigail Williams who acted in a peculiar manner, involving strange shrieks 
and fits. ${ }^{1}$ The local minister, Reverend Samuel Parris was father and uncle respectively to these two original afflicted girls. ${ }^{2}$ This connection is relevant in light of modern assertions that tensions between factions of Salem motivated the witchcraft episode. In particular, Parris was in dispute with opposing factions who wanted to maintain the Village's connection with Salem Town. ${ }^{3}$ Many individuals who were eventually accused of witchcraft came from this opposing faction. ${ }^{4}$

As the winter of 1692 wore on, more girls came down with similar symptoms. Modern medical scholars have since attempted to explain the unusual condition of the afflicted. Asthma, epilepsy and acute delusional psychosis have all been suggested as the cause of the girls' behavior. ${ }^{5}$ However for those in Salem, it was only a small step to involve witchcraft in the diagnosis. At the time, the commoners and the elite of New England communities had a strong belief in the supernatural. ${ }^{6}$ Folklore, literature and indictments acknowledged that witches targeted children. ${ }^{7}$ Witchcraft authorities held that the Devil communicated with witches who could in turn hurt the innocent and even the godly. ${ }^{8}$ This led many in Salem to believe that witchcraft was the only explanation for the girls' 'illness'. Dr William Griggs, who initially examined Abigail and Betty and proclaimed that the girls were "under an Evil Hand", was known to turn to supernatural diagnosis when he could not identify an affliction or find a cure for his patient. ${ }^{10}$

Massachusetts in 1692 operated under a theocracy, following the word of the bible rather than English statute when dealing with witchcraft. The law at the beginning of the Salem episode found that "if any man or woman be a witch (that is hath or consulted with a familiar spirit) they shall be put to death." ${ }^{11}$ It is important to note

\footnotetext{
${ }^{1}$ Peter Charles Hoffer The Salem Witchcraft Trials: A Legal History (University Press of Kansas, United States of America, 1997) at 35.

${ }^{2}$ Hoffer, above n 1, at 36.

${ }^{3}$ Elaine G. Breslaw Witches of the Atlantic World: a historical reader and primary sourcebook (New York University Press, New York, 2000) at 355.

${ }^{4}$ Breslaw, above n3, at 356 .

${ }^{5}$.Hoffer, above n 1 , at 35 .

${ }^{6}$ Hoffer, above n 1 , at 36 .

${ }^{7}$ Hoffer, above n 1, at 37 .

${ }^{8}$ Hoffer, above $\mathrm{n} 1$, at 37 .

${ }^{9}$ Richard Godbeer The Devil's Dominion: Magic and Religion in Early New England (Cambridge University Press, Victoria, 1992) at 179.

${ }^{10}$ Hoffer, above $\mathrm{n} 1$, at 36 .

${ }^{11}$ Book of the Lawes and Liberties 1641.
} 
that it was simply contact with the Devil which constituted witchcraft rather than the infliction of harm on another. ${ }^{12} \mathrm{Up}$ until the Salem witch trials there were very few established cases of witchcraft of this magnitude in New England. ${ }^{13}$ Acquittal was the most common consequence and magistrates required proof, not presumption to convict. $^{14}$

The number of afflicted and those they accused continued to grow. It is here where the Salem episode diverged from previous witchcraft episodes in New England, which usually halted after one or two accusations and arrest. ${ }^{15}$ Initially the group of accusers targeted 'outsiders' within the village-those who already had a tarnished record or who had previously been suspected of witchcraft ${ }^{16}$ Demos suggests that the Puritan society of Salem used witchcraft to scapegoat individuals who were already deemed as "bad" or among the lower ranks of the social order. ${ }^{17}$ Such examples include the first three women accused by Abigail and Betty. Tituba was a Caribbean slave, Sarah Good was a homeless beggar and Sarah Osborne was a decrepit woman. ${ }^{18}$ However the accusers soon turned to the Salem elite, some often accusing their masters such as Mary Warren who named John and Elizabeth Proctor as her afflicters. $^{19}$

Ultimately, over the four-month trial period, an approximate number of 156 people $^{20}$ from twenty four towns and villages ${ }^{21}$ were accused of witchcraft. Nineteen people were hanged for witchcraft and one was pressed to death for refusing to plead. $^{22}$

\footnotetext{
${ }^{12}$ Hoffer, above $\mathrm{n} 1$, at 42 .

${ }^{13}$ John Demos stated that there were 93 complaints of witcheraft between 1638 and 1691, 83 of which lead to indictments from which only twenty convictions arose. Breslaw, above n 3, at 358 .

${ }^{14}$ Hoffer, above n 1 , at 42 .

${ }^{15}$ Paul S. Boyer \& Stephen Nissenbaum Salem Possessed: The social origins of witchraft (Harvard University Press, Massachusetts, 1974) at 4.

${ }^{16}$ Hoffer, above n 1 , at 52.

${ }^{17}$ John Putnam Demos Entertaining Satan: Witchcraft and the Culture of Early New England (Oxford University Press, New York, 1982) at 55.

${ }^{18}$ Godbeer, above n 9, at 180.

${ }^{19}$ Hoffer, above n 1, at 53.

${ }^{20}$ Jane Campbell Moriarty "Wonders of the Invisible World: Prosecutorial Syndrome and Profile Evidence in the Salem Witchcraft Trials" (2001) 26 Vermont Law Review 43 at 44.

${ }^{21}$ Godbeer, above n 9, at 179.

${ }^{22}$ Moriarty, above n 20, at 44.
} 


\section{Legal Procedure}

\section{A. Establishment of Court, Juries and Judges}

The old charter government had been removed by King James II almost a decade before the Salem trials. ${ }^{23}$ On May 14 1692, Governor William Phips arrived in Boston with a new charter establishing Massachusetts as a legal and political entity again. ${ }^{24}$ This new charter upheld the law as established under the old charter, bar where these laws conflicted with English law. ${ }^{25}$

Governor Phips created a court of oyer and terminert to handle the witchcraft trials. $^{26}$ This court was to apply the "law and custom of England" rather than the Massachusetts law as found under the old charter. ${ }^{27}$ Phips appointed a number of his councillors as judges as well as various judges who sat on the Court of Assistants under the old charter. ${ }^{28}$ The majority of these judges were merchants and landowners. ${ }^{29}$

\section{$B$ Evidence Used}

Various forms of evidence were used to prove that the defendants were guilty of witchcraft throughout the examination, hearing and trial process. The majority of evidence used was the testimony and observations of particular behaviour which was said to be caused by witchcraft. ${ }^{30}$ Moriarty divides these causal relationships into two different groups: the relationship between the behaviours of the alleged victims and the witchcraft ("syndromes") and the relationship between the

\footnotetext{
${ }^{23}$ Peter C Hoffer "Invisible World and Criminal Trials: The Cases of John Proctor and OJ Simpson" (1997) 41 American Journal of Legal History at 288.

${ }^{24}$ Marilynne K. Roach The Salem Witchcraft Trials: A Day-by-day Chronicle of a Community under Siege (Taylor Trade Publishing, Maryland, 2004) at 127.

${ }^{25}$ Roach, above $\mathrm{n} 24$, at 127.

${ }^{26}$ A court of Oyer and Terminer comes from the French translation "to hear and decide". This phrase refers to courts which are raised to have criminal jurisdiction over felonious offences. The commission of these courts allowed the judges to try any individual held in gaol for any offence. In this case the court was raised specifically to hear the charges of witchcraft.

${ }^{27}$ Hoffer, above $\mathrm{n} 1$, at 71 .

${ }^{28}$ Hoffer, above $\mathrm{n} 1$, at 72 .

${ }^{29}$ Roach, above n 24, at 144.

${ }^{30}$ Moriarty, above n 20, at 44 .
} 
behaviours of the accused witches and witchcraft. ${ }^{31}$ The use of syndrome evidence was strengthened by the common belief that witchcraft could affect other people's behaviour.

The Salem trials also employed the use of 'folklore' tests, which were initially discouraged from the Salem episode. These included the 'touching test' where a witch was identified if, by touch, they could cure an afflicted person from their fits. ${ }^{32}$ Another form of evidence used was the existence of "witches marks", which were strange or unusual marks found upon the accused's body during an examination by a jury of midwives. ${ }^{33}$ These marks held a central place in witchcraft lore and stemmed from the belief that the Devil's "familiar" needed to suckle from the witch. ${ }^{34}$ Dalton's The Country Justice described such a mark as "some big or little Teat upon their body, and in some secret place, where he (the Devil) sucketh them.",35

Confession was the only form of evidence that was likely to lead to an acquittal. This is because the court aimed to 'rescue' those with repentance from the Devil and reintegrate them into society. ${ }^{36}$ Some of the accused realised that they would not be able to overcome the spectral accusations and therefore decided to confess to a crime that they did not commit. Abigail Hobbs was one such individual who on April 19 admitted to conversing with the Devil and following his instructions to pinch Ann Putnam and Lewis. ${ }^{37}$ This pattern of confessing witches became more pronounced as those accused realised that it was the easiest way to avoid being sentenced to death. ${ }^{38}$

\footnotetext{
${ }^{31}$ At 44.

${ }^{32}$ Hans Sebold Witch-Children (Promethus Books, United States of America, 1995) at 73.

${ }^{33}$ Hoffer, above $\mathrm{n} 1$, at 103.

${ }^{34}$ Hoffer, above $\mathrm{n} 1$, at 103 .

${ }^{35}$ Michael Dalton, The Country Justice cited in Sanford J. Fox Science and Justice: The Massachusetts Witchcraft Trials (The John Hopkins Press, Baltimore, 1968).

${ }^{36}$ Godbeer, above n 9, at 209.

${ }^{37}$ Hoffer, above $\mathrm{n} 1$, at 69.

${ }^{38}$ Sanford J. Fox Science and Justice: The Massachusetts Witchcraft Trials (The John Hopkins Press, Baltimore, 1968) at 76.
} 
The court also placed high credibility on the testimony of confessed witches who named other individuals involved in witcheraft. ${ }^{39}$ However the form of evidence which arguably created the most controversy, was spectral evidence.

\section{Spectral Evidence}

A Background

Spectral evidence is known as the description of physical harm to person or property committed by the 'spectres' of the defendants, described by those who are deemed as the 'afflicted'. ${ }^{40}$ Such evidence was thus the appearance of "out-of-body manifestations of the witches" which could only been seen by those who were afflicted. $^{41}$

This form of evidence had previously been used in witchcraft trials in both England and New England. Such use has been dated back to the twelfth and thirteenth centuries with George Kittredge stating that twenty-two trials involved spectral evidence in the century preceding Salem. ${ }^{42}$ The use of such evidence was endorsed in particular by Chief Justice Matthew Hale in the Bury St. Edmunds case of 1665. In this case two widows were accused of spectrally tormenting their teenage charges. The similarities to the Salem episode were found in the testimony of the young afflicted girls which involved fits and spectral tormenting. "The Three Persons fell into strange and violent fits, fereeking out in a moft fad manner [sic]". ${ }^{44}$ This evidence was allowed to convict the two accused, despite certain inconsistencies

\footnotetext{
${ }^{39}$ Breslaw, above n 3, at 359 .

${ }^{40}$ Daniel G. Payne "Defending against the Indefensible: Spectral Evidence at the Salem Witchcraft Trials" (1993) 129(1) Essex Institute Historical collections 62 at 62.

${ }^{41}$ Hoffer, above n 23, at 295.

${ }^{42}$ George Kittredge Witchcraft in Old and New England citied in Payne, above n40, at 65.

${ }^{43}$ Payne, above n 40, at 68.

${ }^{44}$ Rose Cullender A trial of witches at the assizes held at Bury St. Edmonds for the count of Suffolk on the tenth day of March, 1664 (printed for William Salisbury London, 1682)at 2.
} 
being raised in testimony. With the facts in this case being so similar to the events in Salem, this created a strong precedent to be followed. ${ }^{45}$

The accusers claimed to see spectral activity during examinations, hearings and trials and also provided testimony of spectral harm that occurred outside of court proceedings. Such testimony would include descriptions of being poked, pinched and bruised by the spectres of the accused. ${ }^{46}$ During the trial of Rebecca Nurse, Ann Putnam Snr claimed that "the Apperishtion of Rebekah Nurs did again fall upon me and almost choak me." ${ }^{47}$ Whilst physical harm was not necessary to prove witchcraft, the spectral accusations focused on instances of such harm.

The accusers used cues and signals to make their performance more convincing and synchronised. These cues came from the leaders of the accusers ${ }^{48}$ and also the audience that the girls attracted. ${ }^{49}$ This assertion was reinforced by the accusers' encounter with the community of Ipswich, who were more cautious and sceptical of the girl's accusations than those in Salem Village. Here, the citizens turned their backs on the girls, which deprived them of their familiar cues and led them to abort the performance. ${ }^{50}$

The use of spectral evidence often resembled a carefully planned and timed performance. One of the accusers would cry out that they could see the spectre of one of the accused attacking another accuser, at which point this latter accuser would cry out in pain. ${ }^{51}$ It is not clear whether such coordination was pre-planned or was due to "tacit and spontaneous agreement". ${ }^{52}$ Sebold describes such group behaviour as 'collective reinforcement'. During the hearing of Martha Corey one of the girls cried

\footnotetext{
${ }^{45}$ Payne, above $\mathrm{n} 40$, at 65 .

${ }^{46}$ Hoffer, above n 23, at 295.

${ }^{47}$ University of Missouri-Kansas City "The Trial of Rebecca Nurse” Salem Witchcraft Trials $1692<$ http://law2.umkc.edu/faculty/projects/ftrials/salem/ASA NUR.HTM>

${ }^{48}$ Hoffer suggests that the leaders of the group came from the 'core 7 ' of Betty, Abigail, Ann Putnam Jnr., Mercy Lewis, Elizabeth Hubbard, Mary Walcott and Mary Warren.

${ }^{49}$ Hoffer, above $\mathrm{n} 1$, at 71 .

${ }^{50}$ Sebold, above n 32, at 72 .

${ }^{51}$ Hoffer, above $\mathrm{n} 1$, at 66.

52 Sebold, above n 32, at 74.
} 
out "Gospel witch" upon which the other girls immediately started chanting the same words. Once Martha tried to defend herself the girls began to imitate her every movement and action. ${ }^{53}$

The synchronisation of these performances was seen as confirmation that the accusers were telling the truth about their spectral visions. ${ }^{54}$ However Thomas Hutchinson, an eighteenth century historian, argued that this conformity should have given rise to suspicion. ${ }^{55}$ Hutchinson in fact suggests that this synchronized behaviour indicates that the accusers had read Mather's Memorable Providences of 1688 and had copied the behaviour of the afflicted as described in that text. ${ }^{56}$

This issue of collective reinforcement was exacerbated by the fact that the girls were never examined in private, allowing their "ensemble acting" to thrive. ${ }^{57}$ Had the girls been separated and examined individually, their evidence may not have been as convincing. It is likely there would have been inconsistencies and some accusers would have been unlikely to provide such spectral accounts without the prompts and cues of their leaders.

It is not clear what the accusers' motivations were and whether they completely believed in the spectral accusations they were making. The young age of many of the girls perhaps made them susceptible to being caught up in the hype of the episode, deluding themselves into believing that they were bewitched. It is also possible that once the first accusations had been made, the group realised that they could not repent on what they had said without being charged with perjury. Therefore, they may have continued to make accusations in order to make their supposed ordeal seem more legitimate and therefore to protect themselves.

\footnotetext{
${ }^{53}$ Sebold above n 32, at 74.

${ }^{54}$ Ross J Pudaloff "Witchcraft at Salem: (MIs)representing the subject" (1991) 83 Semiotica 333 at 340.

${ }^{55}$ Pudaloff, above n 54 , at 340.

${ }^{56}$ Pudaloff, above n 54, at 340.

${ }^{57}$ Hoffer, above n 1, at 67.
} 
C How Heavily was Spectral Evidence Relied Upon?

Wendel D. Craker argues that the use of spectral evidence at Salem has been exaggerated and in fact was not a determining factor in the trials and convictions. He claims that whilst this evidence played a significant role in the charges laid, it had very little effect on the outcome of the trials themselves. ${ }^{58}$ Sebold's research found that 79 individuals were charged with spectral evidence only, yet no one from this group of 79 were called to answer the charges in court. ${ }^{59}$ In comparison, Craker provides a list of 30 individuals who were charged with non-spectral acts of witchcraft as well as spectral acts. ${ }^{60}$ Of these 30,24 were brought to trial, 19 of which were prosecuted and hanged as well as Giles Cory who was pressed to death for refusing to plead. Craker uses this information to suggest that non-spectral evidence was more central to the trials than spectral evidence. ${ }^{61}$

Scholarly opinion on this matter is somewhat contradicting. Sarah Kreutter disagrees with Craker, saying that spectral evidence was given "unprecedented weight" in the Salem episode. ${ }^{62}$ Whilst she acknowledges that spectral evidence played an even greater role in the indictments than the trials themselves, she says that this does not diminish the importance of such evidence. Certain individuals such as Sarah Osbourne died of natural causes in prison on charges based solely on spectral evidence. ${ }^{63}$ Pudaloff also states that if spectral evidence was not used, more individuals would have been acquitted, indicating that this evidence was vital for convictions. $^{64}$

Whilst his argument is compelling and supported by convincing data, Craker's view is perhaps ignorant of certain realities. To be found guilty of witchcraft the court needed to establish that the accused had made a covenant with the devil. ${ }^{65}$ The appearance of a spectre in the accused's form was the most reliable determination of such a

\footnotetext{
${ }^{58}$ Wendel D. Craker "Spectral Evidence, Non-spectral Acts of Witchcraft, and Confession at Salem in 1692" (1997) 40(2) The Historical Journal 331at 340.

${ }^{59}$ Craker, above n 58, at 337.

${ }^{60}$ Craker, above n 58, at 341 .

${ }^{61}$ Craker, above n 58, at 341.

${ }^{62}$ Sarah Kreutter "The Devil's Specter: Spectral Evidence and the Salem Witchoraft Crisis" (2011)

2(1) The Spectrum: A Scholars Day Journal at 11.

${ }^{63}$ Kreutter, above n 62, at 12.

${ }^{64}$ Pudaloff, above n 54, at 342.

${ }^{65}$ Carol F. Karlson The Devil in the Shape of a Woman (Penguin Books, Ontario, 1987) at 121.
} 
covenant. ${ }^{66}$ Therefore whilst the court did not try or convict anyone on the basis of spectral evidence alone, it is arguable that without this evidence the court would not have been able to establish the required covenant with the Devil. This argument is supported by Samuel Willard in Some Miscellany Observations ${ }^{67}$, observing that sufficient proof of witchcraft was near impossible to find and as it was deemed to be a 'horrid' crime, society should be more cautious in finding someone guilty of it. ${ }^{68}$ This seems to reflect the more modern notion of a higher standard of proof being required for criminal acts compared to civil issues. Willard stated that to prove witchcraft, causation needed to be established. As it was the spectre who caused the afflictions, and only the accusers could see (or claimed to see) such spectres, this causation would be unable to be established without the admission of spectral evidence. ${ }^{69}$ This clearly shows that spectral evidence played a vital evidential role in the Salem episode.

\section{Use of Evidence was Informed by Popular Beliefs}

The use of spectral evidence needs to be considered in light of the popular beliefs at the time of the trials. During the seventeenth century there was a pervasive and wideheld belief in witchcraft. ${ }^{70}$ This meant that the idea that spectres were causing harm to innocent people was entirely believable and prompted fear in the community. "Thanks to the people's belief in this phenomenon, the girl's testimonies and accusations were taken at face value, instead of as hoaxes or hallucinations." 71 Furthermore, the Salem episode occurred during the pre-science era and therefore those involved turned to their religious and popular beliefs to explain phenomena that they did not understand. Puritan societies of this time were therefore often predisposed to blame suffering on external rather than internal causes. ${ }^{72}$

\footnotetext{
${ }^{66}$ Craker, above n 58, at 343 .

${ }^{67}$ Samuel Willard Some Miscellany Observations Respecting Witchcraft in Dialogue Between $S v$ B...Printed in Philidelphia in 1692 (Boston, 1869).

${ }^{68}$ Hoffer, above n 1, at 129.

${ }^{69}$ Hoffer, above $\mathrm{n} 1$, at 129.

${ }^{70}$ Pudaloff, above $\mathrm{n} 54$, at 341.

${ }^{71}$ Sebold, above n 32, at 72 .

${ }^{72}$ Godbeer, above n 9, at 181 .
} 


\section{Spectral Evidence and Evidential Standards of the Time}

It is important that in examining the use of spectral evidence during the Salem witch trials, that they are analysed in light of the context they appeared in. Such evidence is easily condemned using modern legal and evidential standards as a backboard. Whilst this is an interesting comparison, it does not give any insight to the legality of spectral evidence at the time of the trials. This paper aims to discover how this evidence aligned with the laws, customs and procedures in existence in Salem in 1692.

In making this examination it should be first established that the relevant authorities and decision-makers were focused on following the law. "Lawyers were involved, the rules of evidence were very much considered, and the rule of law was uppermost in the minds of the authorities." ${ }^{, 73}$ The fact that the majority of the trials were delayed until Sir William Phips could establish a new charter and set up the Court of Oyer and Terminer perhaps hints to a limited extent that there was no deliberate attempt to undermine justice. ${ }^{74}$ In comparison to other New England witchcraft episodes, Salem employed a higher level of legal involvement and very little ministerial and religious intervention. ${ }^{75}$ Those involved wanted the trials to follow the correct legal procedures with the process of warrants, indictments, trials, verdicts and executions being strictly followed. ${ }^{76}$

\section{A Guidance Given on the Use of Spectral Evidence}

\section{Case law}

As established, there was precedent for the use of spectral evidence at indictment and trial from the Bury St. Edmonds case. The similarities of the accused' spectral testimony makes this a strong precedent to be followed. However, it needs to be ascertained whether there were other existing rules or guidance as to whether and in what manner such evidence was to be used.

\footnotetext{
73 Pudaloff, above n 54, at 334.

${ }^{74}$ Pudaloff, above n 54, at 334.

${ }^{75}$ John Putnam Demos Entertaining Salem: Witchcraft and the Culture of Early New England cited in Pudaloff, above n 54, at 337.

${ }^{76}$ Pudaloff, above n 54, at 336.
} 


\section{Statute}

There was very little statutory guidance as to the admissibility of spectral evidence. ${ }^{77}$ At the time, witchcraft was condemned by the Body of Liberties 1641 which stated that, "If any man or woman be a witch that is hath or consulteth with a familiar spirit, they shall be put to death.,"78 However there was no mention as to what evidence would be sufficient to prove guilt. ${ }^{79}$ The nature of this legislation reflects the approach of the judges in dealing with spectral evidence where no emphasis was placed on how to establish whether the accused had in fact consulted with the Devil.

This vague legislation allowed significant interpretation of those administering the law. Looking simply at this statutory guidance it seems difficult to condemn a court for applying such evidence incorrectly when so little direction was given.

\section{Legal texts}

Various legal texts were available at the time but it has been suggested that the most useful was Michael Dalton's The Country Justice. ${ }^{80}$ Dalton's publication was used by justices of the peace in England and by New England magistrates. ${ }^{81}$ Dalton warned that in cases of witchcraft there was unlikely to be any direct evidence. As witches dealt in "work[s] of darkness" there may not have been any witnesses to provide testimony of their misdeeds. ${ }^{82}$ He therefore provided some 'presumptions' which could be used to detect witchcraft. One such presumption was spectral evidence: "the appearance of their apparition to the sick party in his fits, and the sick party in his fits naming the parties suspected, and describing their actions." ${ }^{83}$ However, it was clear that such evidence was merely

\footnotetext{
${ }^{77}$ Kruetter above n 62, at 24.

${ }^{78}$ Fox, above n 38, at 37.

${ }^{79}$ Kruetter, above n 62, at 10.

${ }^{80}$ Payne, above $\mathrm{n} 40$ at 67.

${ }^{81}$ Breslaw, above n 3, at 365.

${ }^{82}$ Payne, above $\mathrm{n} 40$, at 68.

${ }^{83}$ Payne, above n 40, at 68.
} 
presumptive and could not be used as conclusive evidence. Other presumptions listed by Dalton were the existence of a familiar, a devil's mark and confession of the accused. The overall effect of this text suggests that while spectral evidence was admissible, it could not provide a conclusive verdict and should be used in conjunction with other presumptions and proofs.

William Perkins was also a respected authority on the matter, however his writing was almost a century old by the time that the Salem trials eventuated. He offered some similar presumptions (not proof) of witchcraft to Dalton, such as curses or quarrels followed by illness, contradictions of the suspected and family ties to other known witches. ${ }^{84}$ Perkins also established more strenuous 'proof' as the 'free and voluntary confession' or the testimony of two proven witches. ${ }^{85} \mathrm{He}$ acknowledged that these "proofs" could be faked or procured by duress and thus advised particular caution in their use. ${ }^{86}$

A further important text was Increase Mather's Cases of Conscience ${ }^{87}$. Mather identified that for a conviction there must be a "free and voluntary Confession" or the testimony of "two credible witnesses, people not bewitched". ${ }^{88}$ This is a similar standard to that set by Perkins.

Therefore, in gathering a consensus from various legal minds of the time, it seems that spectral evidence was available as 'presumptive' evidence but was not to be used to convict without other forms of evidence such as confessions or credible testimony.

\footnotetext{
${ }^{84}$ Hoffer, above n 23, at 296.

${ }^{85}$ Hoffer, above n 23, at 297.

${ }^{86}$ Hoffer above $\mathrm{n} 23$, at 297.

${ }^{87}$ Increase Mather Cases of Conscience Concerning Evil Spirits Personating Men (Boston, 1693).

${ }^{88}$ Pudaloff, above n 54, at 345.
} 


\section{$B$ General Evidential Standards of the Time}

The new charter instructed the judges to conform to English law, however the English law did not hold the same strict evidential rules that exist in today's society. Instead of formal rules of evidence there were general principles to follow. ${ }^{89}$ The idea of truth as decided by reasonable observers was beginning to gain traction in England however juries were often being treated to a large amount of lies and rumours. ${ }^{90}$ Hearsay was also an acceptable form of evidence at this time. $^{91}$

Proof of crime under Massachusetts law under the first charter was to be "convincing and sufficient". ${ }^{92}$ However this does little to instruct juries and judges on how to manage the distinction between psychological and moral wrong. ${ }^{93}$

Here it can be seen that the guidelines and rules which were established in England and Salem were vague and gave very little direction to judges. The door was left open for liberal judicial interpretation and directive.

\section{$C$ Did the Court Follow these Guidelines?}

It is clear that the judges, in allowing spectral evidence, were not acting outside of precedent or statutory power. There was a clear precedent allowing the use of spectral evidence and statute provided no indication of what evidence was appropriate in proving guilt for witchcraft.

In regards to the advice of legal authorities however, it is contentious as to whether to court followed the caution and guidelines expressed in these texts. Using Craker's essential argument, it can be found that the court did follow these guidelines, particularly those established by Dalton. This would be on the basis

\footnotetext{
${ }^{89}$ Hoffer, above n 1 , at 74 .

${ }^{90}$ Hoffer, above n 1 , at 74 .

${ }^{91}$ Hoffer, above $\mathrm{n} 1$, at 75 .

${ }^{92}$ Hoffer, above n 1 , at 74 .

${ }^{93}$ Hoffer, above $\mathrm{n} 1$, at 74 .
} 
that no individual was brought to trial on the basis of spectral evidence alone. ${ }^{94}$ On his analysis the court was acting within the guidelines suggested and required, using spectral evidence in a legally appropriate manner.

However, this conclusion is not as simple as Craker may believe. The one common thread in these guidelines was that spectral evidence alone should not be used to convict-more direct evidence such as confession should be employed. Technically this was followed as no individual was convicted of witchcraft on the basis of merely spectral evidence. However, as discussed, this form of evidence was the evidence which held the most weight at trial and therefore played a vital part in finding those individuals guilty. Therefore whilst the process itself was legitimate and followed guidelines, in reality the effect of the process and evidence used went against the cautions and guidelines of these legal texts. This is because spectral evidence was realistically being used as the sole evidence to convict as it was the only form of evidence which was capable of presenting a definite covenant with the Devil. However it is important to note that such guidelines were merely persuasive and the judges were not bound to follow rules set down from these sources.

\section{Juries}

The individual identities of the jurors from the 1692 trials are unknown, however Hoffer states that they were a cross-section of society: mainly farmers, fishermen and tradesmen with perhaps a few merchants involved. ${ }^{95}$ They were likely to have known both the accused and the accusers, which perhaps made them more susceptible to the performances of the young girls whom the jury is likely to have sympathised with as 'victims'. Such instances where juries were familiar with the accused and the witnesses in a trial, was a common occurrence in small villages such as Salem.

\footnotetext{
${ }^{94}$ Craker, above n 58, at 340 .

${ }^{95}$ Hoffer, above n 23, at 305.
} 
The Salem trials had a much higher conviction rate than the ordinary $50 \%$ chance of conviction by Massachusett's trial juries during the $17^{\text {th }}$ century. ${ }^{96}$ Given the central place that spectral evidence held during the trials, this conviction rate seemed to place a "community seal of approval upon spectral evidence. ${ }^{97}$

In earlier English law, trial juries used their own knowledge to determine the verdict. However by the time of the Salem trials there was a clearly established notion that juries were to hear and see evidence at trial and use this evidence alone to reach a finding of fact, disregarding their own pre-existing conceptions. ${ }^{98}$ Whether this concept was followed at Salem is doubtful, as those involved were likely to have been influenced by their fear and strong belief in the Devil and his work.

Trial juries required instruction from judges as to how to weigh particular pieces of evidence (though this must be carefully distinguished from the jury being told what to believe). ${ }^{99}$ In the Salem witch trials however, the jury needed more help than this: they needed to be able to establish what evidence was real and what was imagined. This dependence has created an argument that perhaps the jurors were unduly influenced by the judges. The trial jurors heard evidence and made their decision in front of the judges and Peter Hoffer argues that they would have been too scared to oppose Chief Justice Stoughton who wanted to allow spectral evidence and condemn those accused. ${ }^{100}$ At the trial of Rebecca Nurse the jury initially gave a verdict of not guilty, but they were reminded by Stoughton that she had as much as confessed during her testimony where in reaction to the testimony of confessed witches including Abigail Hobbs, Nurse had said "What, do these persons give in Evidence against me now, they used to come among us". ${ }^{101}$ After this warning from Stoughton, the jury returned a verdict of guilty, having effectively been bullied into the change of decision. This interaction between judges and the jury paints a vastly different picture to other criminal trials in this period where jurors were well known to bargain facts with the judges and mitigate

\footnotetext{
${ }^{96}$ Hoffer, above n 1 , at 87.

${ }^{97}$ Hoffer, above n 1 , at 87.

${ }^{98}$ Hoffer, above n 1 , at 75 .

${ }^{99}$ Hoffer, above $\mathrm{n} 1$, at 75 .

${ }^{100}$ Hoffer, above $\mathrm{n} 1$, at 87.

${ }^{101}$ Payne, above n 40, at 74 .
} 
sentences where they saw fit. ${ }^{102}$ This suggests that the jury was perhaps suppressed from performing their role effectively. Such instances make it clear that judges had a greater influence over the trials and the verdicts than the juries themselves.

\section{E Judges and Ministers}

It is important to note that we cannot be entirely sure of the opinions of the judges as the original trial transcripts have been missing since the eighteenth century. Only the transcripts from the hearings and pre-trial process have survived. Modern scholars use reproduced accounts of the trials based on evidence at pretrial hearings and reports which have survived.

During the hearings and trials there was a clear structure to the use of spectral evidence which often included the input of Ministers, Interrogators and Judges. John Hathorne, one of the county magistrates who conducted the examinations, seemed to take a directing role in the performances, often prompting fits by asking the accusers to identify the suspects. ${ }^{103}$ Goodbeer argues that Hathorne would often bully the accused, including Sarah Good and Deliverance Hobbs, into confessing. ${ }^{104}$ Whilst the ministers present would urge the girls to reconsider their accusations and the evidence they gave, they did not at any point intervene. ${ }^{105}$

During the examination of the accused, the judges seemed to show bias towards the accusers in unquestionably taking the word of the girls who were seemingly suffering before them. ${ }^{106}$ This becomes particularly critical in light of the fact that the defendants were appearing without counsel and were required to defend themselves. ${ }^{107}$ In such an occurrence, justice was dependant on judges casting an unbiased eye upon the evidence to determine the correct facts. The judges instead of determining whether the accusers were actually suffering, skipped straight to

\footnotetext{
${ }^{102}$ Hoffer, above n 1 , at 88 .

${ }^{103}$ Hoffer, above n 1, at 67.

${ }^{104}$ Godbeer, above n 9, at 207

${ }^{105}$ Hoffer, above n 1, at 67.

${ }^{106}$ Godbeer, above $\mathrm{n} 9$, at 216.

${ }^{107}$ Payne, above n 40, at 69.
} 
deciding whether it was the particular accused who was causing the suffering. ${ }^{108}$ This was evident in the interrogation of Bridget Bishop on 19 April. As soon as Bishop came before the bar Elizabeth Hubbard, Ann Putnam, Abigail Williams and Mercy Lewis all fell into fits. ${ }^{109}$ Instead of asking if her appearance was hurting the afflicted, the judges asked why. This approach is similar to that in the Bury St. Edmonds case where the judges considered "the question of whether witchcraft was involved as a given, and it merely remained to discover who was responsible." 110 This shows that the judges at Salem were disregarding their essential role as fact-finders. Once the accused had used spectral evidence, the general approach was to get the accused witch to confess and repent or prevent them from doing further mischief. ${ }^{111}$ There was no clear effort on the part of the judges to ascertain whether what the girls were saying was true and if it was, that the particular defendant was causing their afflictions.

Judges remained steadfast that what the victim saw was paramount, often dismissing concerns from those outside court. ${ }^{112}$ Thomas Brattle accused Chief Justice Stoughton in particular of assuming the guilt of the accused until he was convinced otherwise and refusing to hear evidence which hinted to their innocence. ${ }^{113}$ This oversight was perhaps allowed due to the unquestioned belief at the time of the power of the Devil and therefore the steadfast belief that the girls were possessed and acting innocently and against their will. ${ }^{114}$ Furthermore, in both England and New England in cases of witchcraft and possession, victims were unquestionably treated as innocent with the remedy being to prosecute the said witch. ${ }^{115}$ Even more inexplicable was the judges approach to dealing with inconsistent spectral testimony by the afflicted persons. This was evident during the testimony of Susannah Sheldon and Ann Putnam Jnr who both claimed that the spectres of the deceased wives of Rev. George Burroughs had told them how Burroughs had murdered them. There is no indication that the judges noted or

\footnotetext{
${ }^{108}$ Payne, above n 40, at 70.

${ }^{109}$ Payne, above n 40, at 69.

${ }^{110}$ Payne, above n 40, at 69.

${ }^{111}$ Payne, above $\mathrm{n} 40$, at 70.

112 Pudaloff, above n 54, at 343.

${ }^{113}$ Godbeer, above n 9, at 207.

114 Sebold, above n 32, at 70.

115 David Hartley "Explaining Salem: Calvinist Psychology and Diagnosis of Possession" (1996) 101 American Historical Review 307 at 311.
} 
took into account that each accuser had a different version of the murders. ${ }^{116}$ Furthermore, Sarah Good was caught out in a lie when she claimed that a spectre had tried to stab her with a knife which had broken during the attack. Upon presentation of the knife it was identified by a young man as one he himself had broken and discarded the day before. Whilst Sarah Good was warned not to tell more lies, she was still allowed to give spectral testimony against other defendants. $^{117}$

However there were instances where the judges showed a certain level of hesitation in allowing spectral evidence. Often they would turn to ministers for help. ${ }^{118}$ Due to the state of theocracy in Puritan Salem, the involvement of ministers in the law was acceptable. Judge John Richards consulted minister Cotton Mather about the use of spectral evidence. Mather cautioned Richards that whilst the afflictions seemed to be caused by something supernatural, the Devil was capable of impersonating others unwillingly. ${ }^{119}$ This correspondence however seemed to have little effect on the judge's actions.

\section{F Critics of Spectral Evidence at the Time}

The Return of Several Ministers dated 15 June 1692 pleaded that caution be taken in the prosecution of witches and specifically highlighted spectral evidence in this regard. ${ }^{120}$ "Presumptions whereupon persons may be committed and, much more, convictions whereupon persons may be condemned, as guilty of witchcrafts, ought certainly to be more considerable than barely the accused person's being represented by a spectre unto the afflicted." ${ }^{121}$ However, convinced that there was a diabolical presence in Salem they urged a cautious continuation of the trials. ${ }^{122}$ The court seized upon this as endorsement for the trials and as such

\footnotetext{
${ }^{116}$ Payne, above n 40, at 76.

${ }^{117}$ Payne, above n 40, at 76.

${ }^{118}$ Hoffer, above $\mathrm{n} 1$, at 75 .

${ }^{119}$ Roach, above n 24, at 153.

${ }^{120}$ Payne, above n 40, at 72.

${ }^{121}$ Payne above n 40, at 72 .

122 Breslaw, above n 3, at 360.
} 
disregarded the previous concerns expressed about the evidence. ${ }^{123}$ Further clerical distrust was exhibited by Samual Willard, minister at Old South, in his sermon against spectral evidence in the summer of $1692 .{ }^{124}$ He stated that the "devil does not ye Consent of ye party in thus representing it". ${ }^{125}$ This directly contradicts the justification of the court's reliance on spectral evidence that the autonomous individual must give the Devil consent to use them as a spectre.

One of the most well known records and critiques of the Salem trials is Cotton Mather's The Wonders of the Invisible World. Whilst Mather is often seen as a central figure in the trials, in reality he had very little direct involvement. His only such involvement was when he prayed and preached at George Burroughs execution on August 19, 1692. ${ }^{126}$ This text initially acknowledges that spectral evidence was unreliable in that the Devil may take the spectral form of innocent persons; "among the Persons represented by the Spectres which now afflict our Neighbours, there will be found some that never explicitly contracted with any of the Evil Angels." 127 This point was also reiterated in Increase Mather's Cases of Conscience where he stated that the Devil could "impose on the Imaginations of Persons Bewitched, and to cause them to Believe that an Innocent, yea that a Pious person does torment them, when the Devil himself doth it." ${ }^{\prime 28}$ However, in what can be seen as an attempt to justify the actions of the court, Cotton Mather states that where the spectral evidence admitted aligned with confessions of the accused, it was acceptable. ${ }^{129}$

Critique and caution also came from those who were involved in the hearing and trial process. Provisional deputy governor Thomas Danforth attempted to scare the girls by telling them that lying would be punishable in a higher court, which lead some girls to retract their testimony. However whilst Danforth's suspicions were

\footnotetext{
${ }^{123}$ Payne, above $\mathrm{n} 40$, at 74.

${ }^{124}$ Pudaloff, above n 54, at 344.

${ }^{125}$ Pudaloff, above $\mathrm{n}$ 54, at 344.

${ }^{126}$ Pudaloff, above n 54, at 339.

${ }^{127}$ Cotton Mather The Wonders of the Invisible World: Being an account of the Tryals of several witches lately executed in New England (printed for John Russell Smith, London, 1862) at 17.

${ }^{128}$ Increase Mather Cases of Conscience Concerning Evil Spirits Personating Men cited in Pudaloff, above $\mathrm{n} 54$, at 345 .

${ }^{129}$ Pudaloff, above n 54, at 340 .
} 
evident, he was sure that the Devil was at work in Salem and so did not enquire into the subject any further. ${ }^{130}$

Most of these critics focused on two fundamental problems in the use of spectral evidence. It was these problems that cast doubt on the legitimacy of using spectral evidence and which created the perception that the prosecutions were unjust.

Firstly, such spectres could only be seen by the accusers. This meant that there was little that could be done to defend such a claim. As such, the appearance of a spectre in the eyes of the afflicted was the equivalent to a sentence rather than simply evidence to be examined. This problem was exacerbated by the reluctance of the judges to determine whether the accuser's spectral accusations were true. This issue was what lead many of the accused to 'confess' to being involved in witchcraft as they realised they would be unable to prove their innocence in the face of spectral evidence.

Secondly, such critics often alleged that the Devil could impersonate an innocent person and thus that the spectres who appeared should not automatically be taken as clear evidence that the person who the spectre attested to be was guilty of witchcraft. The response to this argument by the judges was that consent was required for the Devil to take someone's shape, therefore no innocent person could be seen as a spectre. ${ }^{131}$ The court distinguished between such innocence and guilt on the basis of a uniform application of positing the subject of the spectres as the sole author of their actions. ${ }^{132}$ Therefore the judges at Salem linked the reliability of spectral evidence to the reliability of autonomous individuals. Eventually, after the suspension of the trials Increase Mather acknowledged that the devil could impersonate innocent people, even the godly. ${ }^{133}$

Therefore whilst the court, in using spectral evidence was not directly contradicting established legal standards, they were acting against popular opinion and caution given from those outside of the court. This reaffirms that many

\footnotetext{
${ }^{130}$ Hoffer, above $\mathrm{n} 1$ at 68 .

131 Pudaloff, above n 54, at 341.

132 Pudaloff, above n 54, at 341.

${ }^{133}$ Hoffer, above n 1, at 131.
} 
individuals at the time were aware that the use of such evidence was hindering the due process of the trials.

$G$ Rationale for Allowing Spectral Evidence

Pudaloff argues that if the court had disallowed or cast doubt on the use of spectral evidence then there would have been greater consequences than simply more people being acquitted. He argues that this would have suggested that signs and representations were incapable of being trusted, particularly where they were derived from a sensory mode. ${ }^{134}$ This would have contradicted the Lockean understandings which were in place at the time which highlighted the role of human senses in gaining knowledge. Perhaps the judiciary was not willing to undermine this fundamental school of thought at this time.

\section{$H$ The Eventual Discrediting of Spectral Evidence and the End of the Trials}

An important factor which has been identified in the discrediting of spectral evidence were the reputations of particular accused during the summer and fall of 1692. ${ }^{135}$ In particular, the trials of Rebecca Nurse and John and Elizabeth Proctor showed that prosecution involving spectral evidence would leave no one safe. ${ }^{136}$

Rebecca Nurse was a pious member of the community and the accusations of her involvement in witchcraft shocked many. Nurse was prosecuted predominantly on spectral evidence. Following her declaration of innocence, John Hawthorne stated "Here is never a one in the Assembly but desires it, but if you be guilty Pray God discover you."137

The accusations of John and Elizabeth Proctor spurred 31 Ipswich laymen to sign a petition against the use of spectral evidence in the trials. This petition alleged

\footnotetext{
${ }^{134}$ Pudaloff, above n 54, at 342.

135 Payne, above n 40, at 74.

${ }^{136}$ Payne, above n 40, at 74 .

${ }^{137}$ Payne, above n 40, at 74 .
} 
that the Devil was capable of impersonating innocent persons and as such, the court should halt with its use. ${ }^{138}$ John Proctor himself also petitioned several ministers on July 23, 1692, proclaiming his innocence. ${ }^{139}$ Despite this, both John and Elizabeth were convicted at trial although Elizabeth was given a stay of execution until she had given birth to her child. ${ }^{140}$ These reactions to the trials of the Proctors and Nurse therefore show that judges, juries and townspeople alike were hesitant to condemn those with respectable reputations on the basis of spectral evidence.

At the end of the summer, Increase Mather wrote and presented his work Cases of Conscience $^{141}$ to Governor Phips. Following this in October $1692^{142}$, Phips ordered that the court disregard spectral evidence, disbanded the court of oyer and terminer and temporarily reprieved the five individuals awaiting execution in jail. $^{143}$

Cases of Conscience first acknowledged Willard's assertion that the more 'horrid' the crime, the more caution the accusations required and that whilst there was clear work of the Devil, close attention must be paid to legal evidential rules. ${ }^{144}$ Increase stated that if the evidence did not "infallibly prove the crime against the person accused, [the court] ought not to determine him guilty of it."145 This idea went further than previous cautions from ministers and echoes the modern standard of proof doctrine of 'beyond reasonable doubt'. ${ }^{146}$ This shows that certain figures during the Salem episode were beginning to recognise more modern concepts of evidential standards which would not allow the use of spectral evidence in such a manner. Increase concluded that the evidence of witchcraft must be as clear as evidence of any other felony. He cited a free and voluntary confession as good proof but stated that this could be discredited if the confessor

\footnotetext{
${ }^{138}$ Godbeer, above $\mathrm{n} 9$, at 217.

${ }^{139}$ Alison Games Witchcraft in Early North America (Rowman \& Littlefield Publishers Inc., Maryland, 2010) at 185.

${ }^{140}$ Marion Starkey The Devil in Massachusetts (Dolphin Books, New York, 1961) at 193.

${ }^{141}$ Increase Mather Cases of Conscience Concerning Evil Spirits Personating Men (Boston, 1693).

${ }^{142}$ Carol F. Karlson The Devil in the Shape of a Woman (Penguin Books, Ontario, 1987) at 50.

${ }^{143}$ Hoffer, above $\mathrm{n} 1$, at 130.

${ }^{144}$ Hoffer, above $\mathrm{n} 1$, at 130 .

${ }^{145}$ Hoffer, above $\mathrm{n} 1$, at 130 .

${ }^{146}$ Hoffer, above n 1, at 131.
} 
did not have full faculties, was coerced or included impossible happenings. ${ }^{147}$ Therefore the confession of one witch against another could not be accepted, as such a confession was easily motivated by malice. Increase stated that the testimony of two honest persons who saw or heard the suspect do mischief was also acceptable, however in the trials such testimony only occurred in the form of spectral evidence. ${ }^{148}$ Ultimately Cases of Conscience concluded that "It were better that ten suspected witches should escape than one innocent person should be condemned." 149 This gives the impression that on the basis of spectral evidence, Increase Mather believed that innocent people had been convicted and executed.

Following Phip's instructions, without the admission of spectral evidence, all but three of the 31 who remained accused in January 1693 ended up being acquitted. ${ }^{150}$ This further indicates the extreme weight that spectral evidence had held in prosecuting the earlier defendants. Without spectral evidence, no testimony or other forms of evidence was capable of establishing a covenant with the Devil, resulting in such a high number of acquittals. ${ }^{151}$ Although it must be acknowledged that the ban on spectral evidence did not erase the jurors' memories of the accusers performances, Hoffer argues that the prevention of the accusers vivid testimony in court may have made all the difference in such cases. ${ }^{152}$

Some have argued that this discrediting of spectral evidence and the suspension of the trials shows that the court and authorities were aiming to act in a legal and just manner. "What was done in the dark Time of our Troubles from the Invisible World, all honest Men believe, they did in Conscience of the Oath of God upon them, and they followed unto the best of their Understanding, as we are informed, the Precedents of England and Scotland and other Nations on such dark and doleful Occasion. When they found the Matter beyond the Reach of Mortals, they stopt." ${ }^{, 153}$

\footnotetext{
${ }^{147}$ Hoffer, above n 1 , at 131 .

${ }^{148}$ Hoffer, above $\mathrm{n} 1$, at 131 .

${ }^{149}$ Hoffer, above $\mathrm{n}$ 1, at 131 .

${ }^{150}$ Hoffer, above $\mathrm{n} 1$, at 135 .

${ }^{151}$ Godbeer, above $\mathrm{n} 9$, at 181 .

${ }^{152}$ Hoffer, above n 1, at 135.

${ }^{153}$ Craker, above n 58, at 351.
} 


\section{Fallout from the Trials}

Up until Salem, witchcraft trials had generally been looked upon as beneficial in that they upheld rules and standards and punished those who had made a covenant with the Devil. ${ }^{154}$ In comparison, after the Salem trials, both those involved and commentators almost immediately recognised that the trials were fundamentally flawed. ${ }^{155}$ Immediately after the trials and executions, the use of spectral evidence was almost uniformly condemned for being relied on too heavily. ${ }^{156}$

Various actors in the ordeal attempted to offer an apology or explanation in the aftermath. Governor Phips tried to deflect blame on the court of oyer and terminer and lieutenant governor William Stoughton. ${ }^{157}$ Phips claimed that he had relied on the court to apply the right method for proceedings and that it had acted rashly against seemingly innocent persons. ${ }^{158}$ John Hale posthumously acknowledged that false witnesses and natural causes were responsible for the prosecutions and the symptoms of the afflicted respectively. ${ }^{159}$ The General Court ordered a day of fasting and soulsearching in early 1697 to acknowledge the tragedy that occurred in Salem. ${ }^{160}$ One particular apology and acknowledgment of wrongdoing was particularly late: it wasn't until 1992 that the First Church of Salem voted to readmit Rebecca Nurse and Giles Cory who had been ex-communicated during the Salem episode. ${ }^{161}$

Although the trials and the use of spectral evidence were disavowed by many in the aftermath, they can be seen as conducive to justice in the sense that they produced a consensus on certain issues of representation and evidence. Whilst those executed were condemned on an unjust prosecution and flawed evidential standards, the Salem trials highlighted certain problems with the legal systems and procedures in 1692, allowing these to be fixed and improved in the future. Increase Mather's acknowledgment of proving wrongs to a high degree was a foreshadowing of the

\footnotetext{
${ }^{154}$ Pudaloff, above n 54, at 338.

${ }^{155}$ Pudaloff, above n 54, at 338.

${ }^{156}$ Pudaloff, above n 54, at 344.

${ }^{157}$ Hoffer, above n 1, at 141.

${ }^{158}$ Hoffer, above $\mathrm{n} 1$, at 141 .

${ }^{159}$ Hoffer, above n 1, at 143.

${ }^{160}$ Hoffer, above $\mathrm{n} 1$, at 143 .

${ }^{161}$ Sebald, above n 32, at 68.
} 
modern reasonable doubt threshold in criminal trials. Therefore it could be taken that Salem in 1692 was on the precipice of acknowledging more modern concepts and evidential standards and the witchcraft episode was the trigger point for this.

\section{Conclusion}

This paper has specifically looked at the use of spectral evidence and whether it followed the evidential standards and rules of Salem in 1692. The lack of specific rules of evidence in cases of witchcraft had various effects. Firstly it meant that the officials involved had very little direction as to what evidence was admissible and what would be capable of proving guilt. This meant that they had to turn to other sources of direction such as legal texts, which despite having various common themes did not set out clear evidential rules. Secondly, the lack of clear evidential rules mean that it would be hard to come to the conclusion that the court had acted outside of their authority and legality. Inherent in having scarce and general legal rules and guidelines is liberal judicial interpretation as a result.

Despite this, it was clear that the court aimed to follow procedures and rules where they were available; the authorities did not set out to act illegally. "The court moved with caution and within established guidelines". ${ }^{162}$ Ultimately the court followed available precedent and statutory instruction as well as technically adhering to the guidelines set in legal texts. This is particularly evident where scholarly opinion that spectral evidence alone should not be used to convict, was followed. However spectral evidence was given great weight at the trials-without it a deliberate covenant with the Devil was unlikely to be found. Therefore in reality, given the importance of spectral evidence to the convictions, the court somewhat ignored the caution and guidelines set by the legal texts.

Given the acknowledgement of the problems associated with the use of spectral evidence and the caution advised by many critics, those involved were aware that the use of such evidence was leading to unjust convictions. In particular it was the fact

\footnotetext{
${ }^{162}$ Craker, above n 58 , at 350.
} 
that only the accuser was capable of seeing the spectre and the assertion that the Devil could impersonate innocent victims, which inhibited the rights of the accused and led to seemingly unjust prosecutions. Furthermore, the judges did seem to abandon their role as fact finders, perhaps due to the common fear and popular belief in the dangerous works of the Devil. Perhaps if these judges had cast a more inquisitive and probing eye on the spectral evidence and the problems that it presented, the trials may have halted a lot sooner.

This episode also allowed the use of evidential and procedural rules to be discussed by those who noticed the problems with spectral evidence. This arguably helped the development of law in this area. "The witchcraft crisis at Salem, then, participates in those shifts in representation, power, and the subject which distinguish the Enlightenment and, to a larger extent, the modern world."163

Therefore, spectral evidence at Salem was used within the vague evidential standards of the time and ultimately its use was legitimate. However, the discussion and discernment around such evidence showed that the legal community at Salem were aware that rights were hindered where spectral evidence was used. As such they were on the precipice of acknowledging more stringent and modern evidential and procedural rules. Perhaps without the trials and the shortcomings of spectral evidence becoming evident, these developments may not have occurred as they did.

Word count: $7912 .{ }^{*}$ Includes substantial footnotes

${ }^{163}$ Pudaloff, above n 54, at 348. 


\section{Bibliography}

A Texts

Elaine G. Breslaw Witches of the Atlantic World: a historical reader and primary sourcebook (New York University Press, New York, 2000).

Paul S. Boyer \& Stephen Nissenbaum Salem Possessed: The social origins of witchraft (Harvard University Press, Massachusetts, 1974).

Rose Cullender A trial of witches at the assizes held at Bury St. Edmonds for the count of Suffolk on the tenth day of March, 1664 (printed for William Salisbury London, 1682).

John Putnam Demos Entertaining Satan: Witchcraft and the Culture of Early New Engand (Oxford University Press, New York, 1982).

Sanford J. Fox Science and Justice: The Massachusetts Witchcraft Trials (The John Hopkins Press, Baltimore, 1968).

Alison Games Witchcraft in Early North America (Rowman \& Littlefield Publishers Inc., Maryland, 2010).

Richard Godbeer The Devil's Dominion: Magic and Religion in Early New England (Cambridge University Press, Victoria, 1992).

Peter Charles Hoffer The Salem Witchcraft Trials: A Legal History (University Press of Kansas, Kansas, 1997).

Carol F. Karlson The Devil in the Shape of a Woman (Penguin Books, Ontario, 1987). 
Cotton Mather The Wonders of the Invisible World: Being an account of the Tryals of several witches lately executed in New England (printed for John Russell Smith, London, 1862).

Increase Mather Cases of Conscience Concerning Evil Spirits Personating Men (Boston, 1693).

Marilynne K. Roach The Salem Witchcraft Trials: A Day-by-day Chronicle of a Community under Siege (Taylor Trade Publishing, Maryland, 2004).

Hans Sebold Witch-Children (Prometheus Books, New York, 1995).

Marion Starkey The Devil in Massachusetts (Dolphin Books, New York, 1961.

B Journal Articles

Wendel D. Craker "Spectral Evidence, Non-spectral Acts of Witchcraft, and Confession at Salem in 1692" (1997) 40(2) The Historical Journal 331.

David Hartley "Explaining Salem: Calvinist Psychology and Diagnosis of Possession" (1996) 101 American Historical Review 307.

Peter C Hoffer "Invisible World and Criminal Trials: The Cases of John Proctor and OJ Simpson" (1997) 41 American Journal of Legal History.

Sarah Kreutter "The Devil's Specter: Spectral Evidence and the Salem Witchcraft Crisis" (2011) 2(1) The Spectrum: A Scholars Day Journal. 
Jane Campbell Moriarty "Wonders of the Invisible World: Prosecutorial Syndrome and Profile Evidence in the Salem Witchcraft Trials" (2001) 26 Vermont Law Review 43.

Daniel G. Payne "Defending against the Indefensible: Spectral Evidence at the Salem Witchcraft Trials" (1993) 129(1) Essex Institute Historical collections 62.

Ross J Pudaloff "Witchcraft at Salem: (MIs)representing the subject" (1991) 83 Semiotica 333.

\section{Internet sources}

University of Missouri-Kansas City "The Trial of Rebecca Nurse" Salem Witchcraft Trials $1962<\underline{\text { http://law2.umkc.edu/faculty/projects/ftrials/salem/ASA NUR.HTM> }}$ 